\title{
Is screening and intervention for microalbuminuria worthwhile in patients with insulin dependent diabetes?
}

\author{
K Borch-Johnsen, H Wenzel, G C Viberti, C E Mogensen
}

\begin{abstract}
Objective-To analyse the cost-benefit of screening for and antihypertensive treatment of early renal disease indicated by microalbuminuria in patients with insulin dependent diabetes mellitus.

Design-Previously published data were used to estimate transition probabilities for each step from normoalbuminuria until death. The effect of intervention on urinary albumin excretion rate by antihypertensive treatment was arbitrarily set at three different levels. All direct costs (screening, antihypertensive treatment, treatment of end stage renal failure) were included in the cost-benefit analysis by using real discount rates of $2 \cdot 5 \%$ and $6 \%$.

Setting-Computer simulation.

Subjects-Simulated cohort of 8000 patients.

Main outcome measures-Mortality, incidence of diabetic nephropathy, incidence of end stage renal failure, and costs versus savings.

Results-Assuming treatment effects of $33 \%$ and $67 \%$ median life expectancy increased by four to 14 years, respectively, and the need for dialysis or transplantation decreased by $21 \%$ to $63 \%$. Costs and savings would balance if the annual rate of increase of albuminuria was decreased from $20 \%$ to $18 \%$ a year.
\end{abstract}

Conclusions-Screening and intervention programmes are likely to have life saving effects and lead to considerable economic savings.

\section{Introduction}

Without intervention diabetic nephropathy develops in one third of all patients with insulin dependent diabetes mellitus and is a major threat to their survival and quality of life. ${ }^{12}$ These patients are characterised by increased mortality, ${ }^{34}$ increased risk of proliferative retinopathy, ${ }^{56}$ and increased morbidity and mortality due to vascular disease. ${ }^{78}$ Diabetic nephropathy leads to progressive loss of renal function and will necessitate dialysis or transplantation in most cases. Microalbuminuria (defined as urinary albumin excretion rate of $20-200 \mu \mathrm{g} / \mathrm{min}$ ) predicts development of clinical diabetic nephropathy, ${ }^{9-12}$ thus enabling screening for patients at high risk.

Treatment with antihypertensive drugs decreases the rate of decline of the glomerular filtration rate in patients with nephropathy by $60-70 \%{ }^{1314}$ and mortality seems also to decrease. ${ }^{15}$ In patients with microalbuminuria the long term effect of treatment with antihypertensive drugs has not yet been studied, but short term studies (one to four years) consistently show that the degree of albuminuria is lowered. ${ }^{16} 17$ The qualitative and quantitative effect with respect to postponement or prevention of diabetic nephropathy must, however, be studied in long term prospective controlled clinical trials.

We know that firstly, identification of patients at high risk of developing diabetic nephropathy is possible by screening for microalbuminuria; secondly, antihypertensive treatment of patients with diabetic nephropathy postpones end stage renal failure; and thirdly, antihypertensive treatment in patients with microalbuminuria considerably lowers the rate of albumin excretion and probably postpones or prevents clinical nephropathy. We therefore carried out a simulation study of the likely long term outcome of a programme of screening and antihypertensive intervention for microalbuminuria in patients with insulin dependent diabetes mellitus. We aimed firstly to estimate the effectiveness in terms of survival and need for kidney transplantation and the incidence of overt diabetic nephropathy, and secondly to estimate the efficiency of a screening programme by looking at all direct costs and savings.

We used the results from previous epidemiological studies of the incidence of diabetic nephropathy, the mortality of patients with and without diabetic nephropathy, ${ }^{18}$ and observational data regarding the rate of progression of microalbuminuria. The long term effect of antihypertensive treatment was set at three different levels due to lack of long term experience in patients with microalbuminuria.

\section{Methods}

The flow chart in figure 1 shows the different stages from onset of diabetes until death. Each lambda $(\lambda)$ represents the hazard function for progression or death at each stage adjusted for sex, age, and duration of diabetes. These hazard functions were estimated from

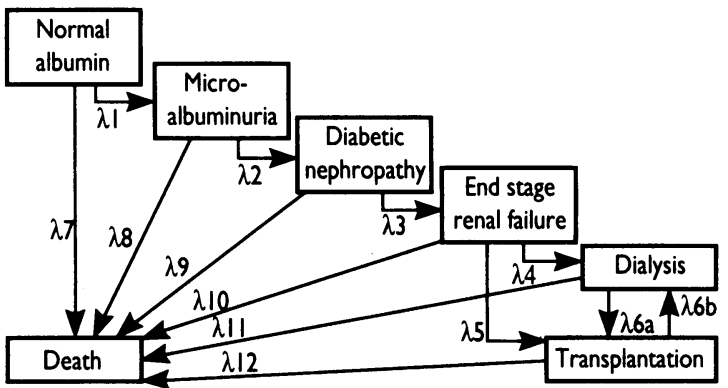

FIG 1-Flow chart for development of diabetic renal disease used in model. Each lambda ( 1-12) represents transition probability specific for age, gender, and duration of diabetes from one step to next in model

a Danish cohort of 2890 patients with insulin dependent diabetes diagnosed from 1933 to 1972 and followed up until death, emigration, or 1 January $1984 .{ }^{18}$ As screening for microalbuminuria was not possible at the time of the study the hazard functions for development of microalbuminuria $(\lambda 1)$ and progression from microalbuminuria to nephropathy $(\lambda 2)$ were estimated assuming firstly, that all patients developing proteinuria emerge from a phase with microalbuminuria and, secondly, the median annual increase rate in the rate of urinary albumin excretion is $20 \%$. This assumption is compatible with the data from the control group in clinical trials ${ }^{19}$ and studies of the natural course of microalbuminuria. ${ }^{9-12} 20$

\section{SCREENING AND TREATMENT PROGRAMME}

The analysis was based on a programme over 30 years with annual screening for microalbuminuria beginning five years after onset of diabetes as the prevalence of microalbuminuria before five years is very low. ${ }^{21}$ Microalbuminuria was defined as two out of
Correspondence to:

$B M F$ 1993;306:1722-3 
three consecutive urine samples showing an excretion rate between 20 and $200 \mu \mathrm{g} / \mathrm{min}$. Treatment was initiated at the onset of microalbuminuria and consisted of antihypertensive treatment with an angiotensin converting enzyme inhibitor. The impact of treatment was calculated by using three different levels of effect, decreasing the proposed progression rate of $20 \%$ in microalbuminuria by $33 \%, 67 \%$, and $100 \%$ (see table I).

\section{ANALYTICAL MODEL}

The study was designed as a cost-benefit analysis, with benefits equivalent to saved costs by preventing or postponing development of nephropathy. The impact of the screening programme was estimated by comparing two scenarios: one describing the natural progression of a cohort of about 8000 patients and a second describing the clinical progression of the same cohort with screening and treatment. The simulation of the cohort and the estimation of hazard function for transition from one stage to the next in figure 1 was based on a Markov-Chain model in combination with a second order Monte Carlo technique ${ }^{22}$ by using the estimates obtained from the Danish cohort. $^{18}$ The model was run by the Institute for Medical Informatics and Biostatistics, Basle, Switzerland.

\section{MORTALITY}

Mortality data from the German Department of Statistics were used as reference for calculation of lost years of life. ${ }^{23}$ In the patients in whom diabetic nephropathy was prevented by the intervention programme the mortality throughout the years was set to be identical to that of diabetic patients who never developed diabetic nephropathy in the Danish study.

In patients who developed diabetic nephropathy the mortality was estimated by using the Danish data. ${ }^{18}$ These data are from a period before the introduction of antihypertensive treatment. Thus the mortality of patients with nephropathy (as evidenced by persistent proteinuria) was overestimated, and the treatment effects in the present study (life expectancy and time to dialysis) were underestimated.

\section{ECONOMIC IMPACT}

The economic evaluation was based on all direct costs including screening costs, costs of antihyperten-

TABLE I-Annual costs associated with screening programme for microalbuminuria in patients with insulin dependent diabetes and with treatment of end stage renal failure

\begin{tabular}{lcc}
\hline & \multicolumn{1}{c}{$\begin{array}{c}\text { Cost per patient per year } \\
\text { (DM (US\$) 1991 prices) }\end{array}$} \\
\cline { 2 - 3 } Screening & Range & Assumption \\
\hline $\begin{array}{l}\text { Cost for screening when result is negative } \\
\text { Cost for screening when result is positive }\end{array}$ & $13(9)$ & $13(9)^{\star}$ \\
$\begin{array}{l}\text { Treatment: } \\
\text { Cost for additional treatment with angiotensive converting } \\
\text { enzyme inhibitor in patients with microalbuminuria }\end{array}$ & $13(9)$ & $13(9)^{\star}$ \\
$\begin{array}{l}\text { Mean annual cost of dialysis } \\
\text { Cost of transplantation, first year }\end{array}$ & $500(350)$ & $500(350)$ \\
Cost of immunosuppressive treatment after transplantation & $20-50000(14-35000)$ & $\begin{array}{l}67500(47000) \dagger \\
45000(31000) \ddagger \\
10000(7000)\end{array}$ \\
\hline
\end{tabular}

*Independent of screening method used as this represents cost for sickness fund. tWeighted average based on types of dialysis used in Germany 1991.

$\ddagger$ Including immunosuppression in first year of treatment.

TABLE II-Estimated effects of antihypertensive treatment in patients with microalbuminuria

\begin{tabular}{|c|c|c|c|c|c|}
\hline \multirow[b]{2}{*}{ Strategy } & \multirow[b]{2}{*}{$\begin{array}{c}\text { Efficacy of } \\
\text { antihypertensive } \\
\text { treatment }\end{array}$} & \multirow[b]{2}{*}{$\begin{array}{l}\text { Annual rate of } \\
\text { increase of urinary } \\
\text { albumin excretion }\end{array}$} & \multirow{2}{*}{$\begin{array}{l}\text { Duration from } \\
\text { microalbuminuria } \\
\text { to nephropathy }\end{array}$} & \multicolumn{2}{|c|}{ Median age at onset } \\
\hline & & & & Nephropathy & $\begin{array}{l}\text { End stage renal } \\
\text { failure* }\end{array}$ \\
\hline $\begin{array}{l}\text { No screening } \\
\text { Screening } \\
\text { Screening } \\
\text { Screening }\end{array}$ & $\begin{array}{c}0 \\
33 \% \\
67 \% \\
100 \%\end{array}$ & $\begin{array}{l}20 \% \\
13 \cdot 4 \% \\
6 \cdot 6 \% \\
0 \%\end{array}$ & $\begin{array}{c}13 \text { Years } \\
19 \text { Years } \\
37 \text { Years } \\
-\end{array}$ & $\begin{array}{l}46 \text { Years } \\
52 \text { Years } \\
70 \text { Years } \\
\text { - }\end{array}$ & $\begin{array}{l}52 \text { Years } \\
58 \text { Years } \\
76 \text { Years } \\
\end{array}$ \\
\hline
\end{tabular}

*Progression rate from clinical nephropathy to end stage renal failure was assumed to be independent of screening and intervention programmes and was set to be identical with progression in group not screened and thus with situation before introduction of antihypertensive treatment. sive treatment in the case of microalbuminuria and nephropathy, costs of dialysis, costs of kidney transplantation, and costs of immunosuppressive agents in cases of transplantation (table I). All costs were based on the 1991 prices in Germany as reimbursed by the sickness funds, and the economical analysis was carried out from the point of view of the German sickness fund.

A broader viewpoint would certainly show greater benefits, especially to society. Most of the savings, however, would not occur with the financier who pays most of the costs-the sickness funds-but with the government and employers. Furthermore, indirect costs (for example, loss of working capacity due to dialysis) and indirect savings (for example, increased number of active years of work) are influenced by variable factors such as educational level, rate of unemployment, etc. Costs due to potential side effects of the antihypertensive treatment were not included in the analysis but severe side effects are rare with the antihypertensive treatment suggested here. As the calculations were based only on direct costs and savings the present study underestimates the total savings associated with the screening programme. The number of visits to diabetes centres was assumed not to be affected by the programme as urinary albumin excretion was measured only once a year and thus could be done at a routine consultation.

As the costs (and saved costs) will occur at different points in time discounting of the cash flow was necessary to make the economic consequences of the alternative programmes comparable. The calculations were performed with two different real discount rates: $2.5 \%$ and $6 \%$ a year, respectively.

All costs and savings are given in deutschmarks (DM) according to the recommendations of the Organisation for Economic Cooperation and Development as the calculations of costs and savings were based on the German sickness fund subsidiaries.

\section{Results}

Incidence of nephropathy and end stage renal failureTable II shows the estimated effect of antihypertensive treatment on the rate of increase of urinary albumin excretion and on the duration from onset of microalbuminuria to nephropathy. Onset of nephropathy would be delayed by six years, assuming an effect of $33 \%$, while a $67 \%$ effect would delay onset by 24 years. Because of the delayed onset of nephropathy the patients would be older when developing nephropathy. Thus some of the patients would die from other natural causes or diseases before entering end stage renal failure. The need for kidney transplantation or dialysis would therefore decrease by $21 \%$ and $63 \%$ assuming an effect of treatment of $33 \%$ and $67 \%$, respectively.

Mortality-Figure 2 shows the median life expectancy for the subgroup of patients developing microalbuminuria. The median life expectancy increased by four to 14 years, and the effect was greatest in patients who developed diabetes during childhood. As only one out of three patients would develop diabetic nephropathy the increase in median life expectancy was lower when calculated on the entire cohort (two to five years). The increase in life expectancy was 50\% higher in patients developing diabetes before the age of 5 years than in patients developing diabetes after the age of 25 years.

Costs and savings-Figure 3 shows the relation between real discount rate, treatment efficacy, and net savings. Each line in the figure represents a constant level of net savings per patient over the entire life time of the patient. The line denoted 0 represents the point of balance between costs and savings. With a real 


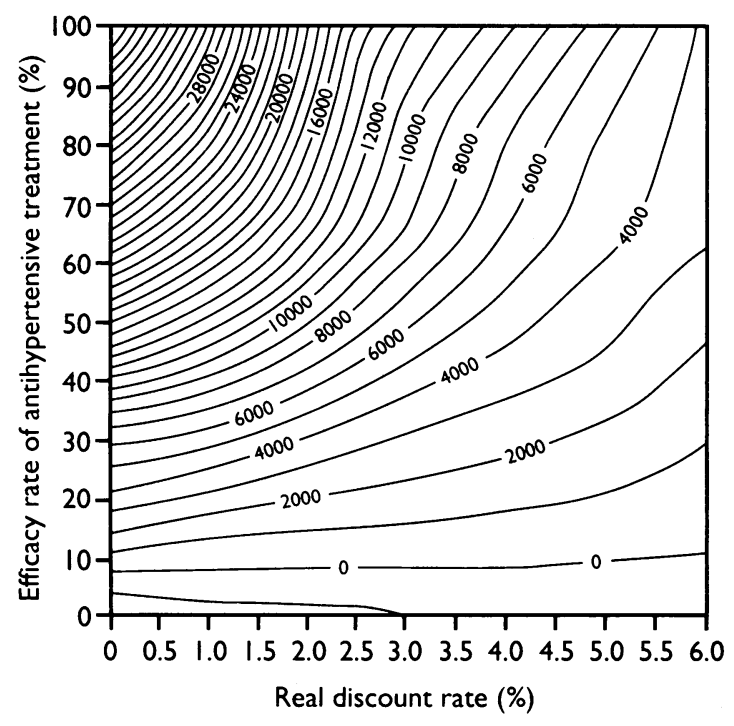

FIG 3-Net savings (in DM) by real discount rate (\%) and efficacy of antihypertensive treatment (\% reduction in annual increase of urinary albumin excretion rate). Each solid line represents constant level of savings per patient. Line denoted 0 represents line with balance between costs and savings

discount rate of $6 \%$ an effect of $11 \%$ of the antihypertensive treatment would be needed to balance costs and savings. With a real discount rate of $2.5 \%$ an $8 \%$ effect would be needed. Thus, reducing the annual rate of increase of albuminuria from 20 to $18 \%$ would balance costs and savings. Figure 4 shows the net savings for two different levels of treatment effect and two different discount rates. The savings per patient would range from DM $1500(\$ 800)$ (real discount rate of $6 \%$, effect of treatment of 33\%) and DM $11000(\$ 7700)$ (real discount rate of $2 \cdot 5 \%$, effect of treatment of $67 \%$ ).

FIG 4-Costs saved per patient (in DM 1000) assuming three different treatment effects (33\%, $67 \%$, and $100 \%$ ) and two different real discount rates $(2 \cdot 5 \%$ closed bars, $6 \%$ open bars decreased considerably $(60-70 \%)$ by treatment with antihypertensive drugs ${ }^{1314}$ and that strict metabolic control $^{19}$ and antihypertensive treatment seems to reduce the progression of microalbuminuria, ${ }^{1617}$ although long term data are still lacking.

Initiating a screening programme is, however, both expensive and time consuming. Furthermore, screening programmes should be initiated only if they benefit patients (survival or quality of life) or society (health care costs). It is necessary to decide on priorities between programmes, and setting different programmes in order of priority raises the need for evaluation of efficiency for each programme.

In accordance with a recent American study ${ }^{25}$ the present analysis showed that an intervention programme which includes screening for microalbuminuria and early treatment with antihypertensive drugs would be neutral with respect to costs and savings if antihypertensive treatment could reduce the annual increase in the rate of albumin excretion by 8 to $10 \%$ (from 20 to $18 \%$ a year). The programme would offer considerable life saving and a reduced incidence of end stage renal failure at treatment effects of $33 \%$ and $67 \%$.

In the present design screening for albuminuria was performed on an annual basis. If one urine sample screened showed microalbuminuria, testing should be repeated twice to confirm the diagnosis..$^{26}$ Annual screening was chosen on the basis of a likely increase in the rate of urinary albumin excretion of $20 \%$ a year and a day to day variability between individual patients of $40 \% .{ }^{27}$ More frequent testing is unnecessary as the patients are likely to remain in the lowest range of microalbuminuria $(20-60 \mu \mathrm{g} / \mathrm{min})$ for a period of six years. ${ }^{2 x}$

The intervention used in this programme was antihypertensive treatment, which has proved effective in patients with diabetic nephropathy. Two different studies have shown that the rate of decline in the rate of glomerular filtration is reduced by about $60 /$ $70 \%$ by antihypertensive drugs. ${ }^{1314}$ In concordance with this Mathiesen et al found that the eight year survival of patients with nephropathy increased from $49 \%$ to $87 \%$ after the introduction of antihypertensive drugs. ${ }^{15}$ In patients with microalbuminuria it is still unknown whether antihypertensive drugs affect the long term prognosis (that is, risk of developing end stage renal failure and mortality). Microalbuminuria can be lowered (and in several cases normalised) by antihypertensive drugs, and several studies (table III) have consistently shown that antihypertensive drugs reduce microalbuminuria in patients with insulin dependent diabetes. Most of these studies were small and of short duration (one to two years). In the only

TABLE III-Trials of antihypertensive treatment in young patients with insulin dependent diabetes mellitus and microalbuminuria but no hypertension

\begin{tabular}{|c|c|c|c|c|c|c|c|}
\hline \multirow[b]{2}{*}{ Study } & \multirow{2}{*}{$\begin{array}{l}\text { Randomised } \\
\text { with parallel } \\
\text { controls }\end{array}$} & \multirow{2}{*}{$\begin{array}{l}\text { Double } \\
\text { blind }\end{array}$} & \multirow[b]{2}{*}{ Treatment } & \multirow{2}{*}{$\begin{array}{c}\text { No of } \\
\text { patients and } \\
\text { duration of } \\
\text { treatment }\end{array}$} & \multicolumn{3}{|c|}{ Outcome measures } \\
\hline & & & & & Microalbuminuria & Development of proteinuria & Glomerular filtration rate \\
\hline Christensen et al $1987^{33}$ & $\mathrm{No}^{\star}$ & No & $\begin{array}{l}\beta \text { Blockers and } \\
\text { diuretics }\end{array}$ & 6,5 years & Reduced & Not seen & Stable \\
\hline Marre et al $1988^{16}$ & Yes & Yes & $\begin{array}{l}\text { Angiotensin } \\
\text { converting enzyme } \\
\text { inhibitor }\end{array}$ & 20,1 year & Reduced & Preventiont & $\begin{array}{l}\text { Stable on angiotensin converting } \\
\text { enzyme inhibitorf }\end{array}$ \\
\hline $\begin{array}{l}\text { Melbourne Diabetic } \\
\text { Nephropathy study Group } \\
1991^{34}\end{array}$ & Yes & No & $\begin{array}{l}\text { Angiotensin } \\
\text { converting enzyme } \\
\text { inhibitor } v \text { calcium } \\
\text { blocker }\end{array}$ & 43,1 year & Reduced & Not seen. & Stable \\
\hline Mathiesen et al $1991^{17}$ & Yes & No & $\begin{array}{l}\text { Angiotensin } \\
\text { converting enzyme } \\
\text { inhibitor and } \\
\text { thiazide }\end{array}$ & 44,4 years & Reduced & $\begin{array}{l}\text { Prevented by angiotensin } \\
\text { converting enzyme inhibitor }\end{array}$ & $\begin{array}{l}\text { Stable (angiotensin converting } \\
\text { enzyme inhibitor) } \\
\text { Fall (placebo) }\end{array}$ \\
\hline $\begin{array}{l}\text { European Microalbinuria } \\
\text { Captopril Study Group } \\
1992^{29}\end{array}$ & Yes & Yes & $\begin{array}{l}\text { Angiotensin } \\
\text { converting enzyme } \\
\text { inhibitor }\end{array}$ & 92,2 years & $\begin{array}{l}\text { Reduced by angiotensin } \\
\text { converting enzyme } \\
\text { inhibitor }\end{array}$ & $\begin{array}{l}\text { Prevented by angiotensin } \\
\text { converting enzyme inhibitor }\end{array}$ & Stable \\
\hline Hallab et al $1993^{35}$ & Yes & Yes & $\begin{array}{l}\text { Angiotensin } \\
\text { converting enzyme } \\
\text { inhibitor } v \text { thiazide }\end{array}$ & 21,1 year & $\begin{array}{l}\text { Reduced by angiotensin } \\
\text { converting enzyme } \\
\text { inhibitor }\end{array}$ & Not seen & Stable \\
\hline
\end{tabular}

*Self controlled. $\nmid$ Non-significant tendency for prevention by angiotensin converting enzyme inhibitor. $¥ N o n$-insignificant tendency to fall on placeo. 
long term study (four years' duration) a considerable number of patients in the control group developed proteinuria and an associated decline in the glomerular filtration rate whereas this was not seen in the group treated with angiotensin converting enzyme inhibitors. ${ }^{17}$ This protective effect of treatment with angiotensin converting enzyme inhibitors was recently confirmed in a multicentre controlled clinical trial. ${ }^{29}$ In patients with an albumin excretion rate between 20 and $200 \mu \mathrm{g} / \mathrm{min}$, four out of 44 actively treated patients progressed to clinical nephropathy whereas this was the case in 12 out of 44 controls. The annual rate of increase of the albumin excretion rate was reduced from $18 \cdot 3 \%$ to $2 \cdot 1 \%$ by captopril. As development of proteinuria is consistently associated with a fall in glomerular filtration rate the reduction or stabilisation in microalbuminuria will probably preserve renal function. ${ }^{28}{ }^{30}$ Antihypertensive treatment in microalbuminuria is therefore likely to postpone considerably the development of proteinuria and to postpone or prevent development of end stage renal failure.

In patients with diabetic nephropathy the clinical effect of antihypertensive drugs seems to be a $60-70 \%$ reduction in the rate of decline of the glomecular filtration rate. In patients with microalbuminuria the precise effect cannot be estimated on the basis of the present studies, but in the study by Mathiesen et al $30 \%$ of the control group developed overt nephropathy compared to none in the actively treated group,${ }^{17}$ and in the multicentre trial the control group was three times more likely to develop overt nephropathy than the actively treated group (30\% versus $10 \%){ }^{29}$

The risks of developing nephropathy and mortality rates were calculated from the previously published Danish cohort study of 2890 patients with insulin dependent diabetes. ${ }^{18}$ Information regarding microalbuminuria was not available as the study covered a period when tests for microalbuminuria had not yet been developed. Thus the observed mortality for patients without nephropathy in that study included patients with normal albuminuria as well as microalbuminuria. More recent studies of patients with noninsulin dependent diabetes ${ }^{31}$ and subjects without diabetes $^{32}$ show a clear excess mortality in patients with microalbuminuria, predominantly due to cardiovascular disease. Whether this is also the case in patients with insulin dependent diabetes is unknown. If there is an excess mortality in patients with insulin dependent diabetes and microalbuminuria, irrespective of intervention, our analysis would overestimate the true effect on survival. The costs and the benefits are, however, not affected by this as we have not included the increased life expectancy in our economic analysis.

In conclusion we have shown that establishment of screening programmes for microalbuminuria for all patients with insulin dependent diabetes would be economically neutral at a treatment effect of $10 \%$. With an estimated treatment effect of $33 \%$ to $67 \%$ the screening and intervention programme would lead to substantial increases in life expectancy and reduction in the incidence of end stage renal failure. We therefore recommend a screening programme for all patients with insulin dependent diabetes, including annual measurement of urinary albumin excretion rate. Based on the data from intervention studies we would also recommend that very early antihypertensive treatment be carefully considered. Screening programmes should be established with the purpose of monitoring the effects and the efficiency of the programme.

The statistical analysis was performed with assistance from Dr Bergemann and $\mathrm{Mr}$ Mast, Institute for Medical Informatics and Biostatistics, Basle.
1 Krolewski AS, Warram JH, Christlieb AR, Busick EJ, Kahn CR. The changing natural history of nephropathy in type 1 diabetes. $A m \mathcal{J} \mathrm{Med}$ 1985;78:785-94.

2 Kofoed-Enevoldsen A, Borch-Johnsen K, Kreiner S, Nerup J, Deckert T Declining incidence of persistent proteinuria in type 1 (insulin-dependent) diabetes mellitus in Denmark. Diabetes 1987;36:205-9.

3 Borch-Johnsen $\mathrm{K}$. The prognosis of insulin-dependent diabetes mellitus. An epidemiological approach. Dan Med Bull 1989;36:336-48.

4 Borch-Johnsen K, Andersen PK, Deckert T. The effect of proteinuria on relative mortality in type 1 (insulin-dependent) diabetes mellitus. on relative mortality in
Diabetologia 1986;28:590-6.

5 Krolewski AS, Warram JH, Rand LI, Christleib AR, Busick EJ, Kann CR. Risk of proliferative diabetic retinopathy in juvenile-onset type 1 diabetes: 40 year follow-up study. Diabetes Care 1986;9:443-52.

6 Kofoed-Enevoldsen A, Jensen T, Borch-Johnsen K, Deckert T. Incidence of retinopathy in type 1 (insulin-dependent) diabetes: association with clinical nephropathy. I Diabetic Complications 1987;1:96-9.

7 Jensen T, Borch-Johnsen K, Kofoed-Enevoldsen A, Deckert T. Coronary heart disease in young type 1 (insulin-dependent) diabetic patients with and without diabetic nephropathy: Incidence and risk factors. Diabetologia 1987;30:144-8.

8 Borch-Johnsen K, Kreiner S. Proteinuria value as predictor of cardiovascular mortality in insulin dependent diabetes mellitus. BM7 1987;294:1651-4.

9 Viberti GC, Jarrett RJ, Mahmud U, Hill RD, Argyropoulos A, Keen H. Microalbuminuria as a predictor of clinical nephropathy in insulin Microalbuminuria as a predictor of clinical

10 Mogensen CE, Christensen CK. Predicting diabetic nephropathy in insulindependent patients. N Engl I Med 1984;311:89-93.

11 Mathiesen ER, Oxenbøll B, Johansen K, Svendsen PAa, Deckert T. Incipien nephropathy in type 1 (insulin-dependent) diabetes. Diabetologia 1984;26: 406-10.

12 Parving HH, Oxenbell B, Svendsen PAa, Christiansen JS, Andersen AR Early detection of patients at risk of developing diabetic nephropathy: longitudinal study of urinary albumin excretion. Acta Endocrinol (Copenh) 1982;100:550-5.

13 Mogensen CE. Long term antihypertensive treatment inhibiting progression of diabetic nephropathy. $B M$ J 1982;285:685-8.

14 Parving $\mathrm{H}-\mathrm{H}$, Andersen AR, Smidt UM, Svendsen PAa. Early aggressive antihypertensive treatment reduces the rate of decline in kidney function in diabetic nephropathy. Lancet 1983;i:1175-9.

15 Mathiesen ER, Borch-Johnsen K, Jensen DV, Deckert T. Improved survival in patients with diabetic nephropathy. Diabetologia 1989;32:884-6.

16 Marre M, Chatellier G, Leblanc H, Guyene TT, Menard J, Passa P. Prevention of diabetic nephropathy with enalapril in normotensive diabetics with microalbuminuria. BMf 1988;297:1092-5.

17 Mathiesen ER, Hommel E, Giese J, Parving H-H. Efficacy of captopril in postponing nephropathy in normotensive insulin dependent diabetic patients with microalbuminuria. $B M \mathcal{F}$ 1991;303:81-7.

18 Ramlau-Hansen H, Bang Jespersen NC, Andersen PK, Borch-Johnsen K Deckert T. Life insurance for insulin-dependent diabetics. Scandinavia Actuarial fournal 1987:19-36.

19 Feldt-Rasmussen B, Mathiesen ER, Jensen T, Lauritzen T, Deckert T. Effect of improved metabolic control on loss of kidney function in type 1 (insulindependent) diabetic patients: an update of the Steno Studies. Diabetologia 1991;34:164-70.

20 Christensen CK. The pre-proteinuric phase of diabetic nephropathy. Dan Med Bull 1991;38:145-59.

21 Marshall SM, Albert KGMM. Comparison of the prevalence and associated features of abnormal albumin excretion in insulin-dependent and noninsulin-dependent diabetes. $O$ I Med 1989;70:61-71.

22 Doubilet P, Begg CB, Weinstein MC, Braun P, McNeil B. Probabilistic sensitivity analysis using Monte Carlo Simulation. A practical approach Med Decis Making 1985;5:157-77.

23 Statistisches Bundesamt, ed. Statistisches Jahrbuch 1990 für die Bundesrepublik Deutschland. Stuttgart: Metzler-Poeschel Verlag, 1990.

24 Krans HMJ, Porta M, Keen H. Diabetes care and research in Europe: the $S$ Vincent declaration action programme. Implementation document. Giomale Italiano di Diabetologia 1992;12(suppl 2):1-56.

25 Siegel JE, Krolewski AS, Warram JH, Weinstein MC. Cost-effectiveness of screening and early treatment of nephropathy in patients with insulindependent diabetes mellitus. Fournal of American Society of Nephrology 1992;3:3111-9.

26 Mogensen CE, Chachati A, Christensen CK, Close CF, Deckert T, Hommel $\mathrm{E}$, et al. Microalbuminuria; an early marker of renal involvement in $\mathrm{E}$, et al. Microalbuminuria; an early mark
diabetes. Uraemia Investigations 1986;9:85-95.

27 Feldt-Rasmussen B, Mathiesen ER. Variability of urinary albumin excretion in incipient nephropathy. Diabetic Nephropathy 1984;3:101-3.

28 Mogensen CE, Petersen MM, Hansen K, Christensen CK. Micro-albuminuria and the organ damage concept in anti-hypertensive therapy for patients with insulin-dependent diabetes mellitus. 7 Hyperten 1992;10(suppl 1):S43-S51.

29 Mogensen CE, on behalf of the European Microalbuminuria Captopril Stud Group. Captopril delays progression to overt renal disease in insulindependent diabetes mellitus patients with microalbuminuria. $7 \mathrm{Am} \mathrm{So}$ Nephrol 1992;3:336(A).

30 Mogensen CE, Østerby R, Hansen KW, Damsgaard EM. Blood pressure elevation versus abnormal albuminuria in the genesis and prediction of renal disease in diabetes. Diabetes Care 1992;15:1192-204.

31 Damsgaard EM, Froland A, Jorgensen OD, Mogensen CE. Eight to nine year mortality in known non-insulin dependent diabetics and controls. Kidney Int 1992;41:731-5.

32 Damsgaard EM, Freland A, Jorgensen OD, Mogensen CE. Microalbuminuria as predictor of increased mortality in elderly people. BMF 1990;300:297 300.

33 Christensen CK, Mogensen CE. Antihypertensive treatment: long term reversal of progression of albuminuria in incipient diabetic nephropathy. A longitudinal study of renal function. 7 Diabetic Complications 1987;1:45-52.

34 Melbourne Diabetic Nephropathy Study Group. Comparison between perindopril and nifedipine in hypertensive and normotensive diabetic patients with microalbuminuria. $B M 7$ 1991;302:210-6.

35 Hallab M, Gallois Y, Chattelier G, Rohmer V, Fressinaud P, Marre M. Comparison of reduction in microalbuminuria by enalapril and hydrochlorthiazide in normo BMf 1993;306: 1 75-82.

(Accepted 15 April 1993) 